\title{
William Shakespeare: diálogos intertextuais e intermidiáticos no filme Anônimo
}

\author{
Ádria Graziele Pinto e Ana Cláudia Munari Domingos
}

\section{Introdução}

É unânime a opinião de que a grandeza de Shakespeare e, sobretudo, sua permanência se encontram justamente na variedade de personas criadas por ele. Apesar do vasto número de obras que compôs, eternizando temas atemporais a partir de peças como Romeu e Julieta, Hamlet, Otelo e Macbeth, entre outras, pouco se sabe sobre sua vida pessoal. Bárbara Heliodora (2008) afirma que boa parte da biografia do poeta e dramaturgo é desconhecida, consistindo sobretudo de suposições e colagens de fragmentos coletados.

Apresentando um volume considerável de produções em uma época de intensa atividade cênica e de presença do público no teatro, William Shakespeare consagrou-se como um dos nomes mais citados e reproduzidos pelo cinema. É possível encontrar, em uma rápida pesquisa pelas plataformas cinematográficas disponíveis, filmes que retratam tanto suas obras como sua vida. Essa filmografia inclui desde roteiros que buscaram transmidiar o texto de suas obras, como é o caso da aclamada tragédia Hamlet, em duas das principais adaptações de mesmo nome, a de 1948, de Lawrence Olivier, e a de 1996, dirigida e estrelada por Kenneth Branagh, considerada uma das adaptações mais ousadas dos dramas de Shakespeare, até filmes que também exploram sua vida pessoal, como é o caso de Shakespeare apaixonado, filme dirigido por John Madden e lançado em 1998, com roteiro assinado por Marc Norman e pelo dramaturgo Tom Stoppard. Nessa obra, a construção dos diálogos é feita por meio da inclusão de alguns trechos de suas peças, colocados nas vozes 
tanto do ator que encarna Shakespeare na trama, quanto das outras personagens. Assim, além de encantar pela fábula engenhosa e por sua estética, que reproduz e engendra a atmosfera de criação de Shakespeare, a história fascina pelas muitas referências intertextuais que podem ser reconhecidas pelo espectador e que expandem o efeito do filme.

Este trabalho se debruça justamente sobre uma dessas obras voltadas para a polêmica relacionada à biografia de Shakespeare, Anônimo (2011), de Roland Emmerich, que, aproveitando-se do feliz casamento entre as lacunas biográficas e o interesse das plateias, constrói uma história a partir da hipótese de que a autoria atribuída ao bardo não passaria de uma invenção criada para esconder o verdadeiro responsável pela criação da obra dramatúrgica mais famosa do mundo, Edward de Vere, o Conde de Oxford.

Sem perder de vista a genialidade e o caráter atemporal das peças de William Shakespeare, neste trabalho analisamos a figuração do dramaturgo inglês como alegoria no filme Anônimo (2011), a partir de vários processos intermidiais. Consideramos que a construção de Shakespeare como personagem que contraria a imagem já cristalizada de um dramaturgo consagrado se dá a partir de diferentes estratégias intertextuais (GENETTE, 2010) e intermidiais (WOLF, 1999; CLÜVER, 2007; ELLESTRÖM, 2017), que amparadas pelo “impulso alegórico" (OWENS, 2004), característico da ficção que se alimenta da história e de seus vazios, busca, através da linguagem cinematográfica, representar e transmidiar a mídia teatro com a intenção de construir um verossímil que se apresente como factual. É através desse processo que é possível reconstruir a imagem do bardo, relacionando-o ao contexto factual e à produção dramática que a ele é atribuída, enquanto se preenchem os vazios pela invenção.

\section{Dos palcos para as telas: uma obra intertextual e intermidiática}

Seja diante da estrutura esférica do Globe, ou diante da tela plana de um cinema, não é por nada o barulho: a força das tramas de Shakespeare, que traçam o destino de personagens complexas, pode facilmente impressionar o especta- 
dor. Tomemos como exemplo o epílogo da tragédia Otelo (1603-4), o monólogo final de seu protagonista, ao ser encenado, impressiona não apenas pelo peso das palavras ditas, mas, também, pelo fato de Otelo se apunhalar depois de reconhecer seus erros. Em contrapartida, no filme $O$ (2001), uma tradução transcultural de Otelo, dirigida por Tim Blake Nelson, a dramaticidade contida no discurso final da personagem não está concentrada nos movimentos corporais, tampouco na força impressa na arma que dispara contra o peito de Odin, mas, sim, na manipulação da imagem, um artifício próprio da sétima arte, ao congelar a cena e prolongar deliberadamente o momento em questão, proporcionando outra percepção ao espectador. Esse efeito do texto cênico e do texto cinematográfico advém de possibilidades de leitura da força dos versos de Shakespeare, em sua capacidade de compreender e revelar a alma humana em seus mais idiossincráticos elementos.

Tanto a partir das teorias do cinema como da literatura comparada espaço das relações entre a arte da palavra e outras linguagens -, o conceito atual de "adaptação" transformou-se até a bem-vinda superação da relação entre original e cópia, abandonando tanto aquela constante busca pela fidelidade de seus realizadores quanto, talvez não da mesma forma, a expectativa do público de um reencontro com sentidos já completamente conhecidos. As convicções contemporâneas sobre a relação entre um objeto cultural e sua adaptação para outra linguagem tornaram maleáveis conceitos que recentemente eram inflexíveis, conferindo um caráter de tradução ao resultado dessa ação de transmidiar.

Para Thaïs Flores Nogueira Diniz (1999), a ampliação do significado presente no termo "tradução" mostra-se relevante para que determinada obra possa ser considerada uma adaptação de outra, já que a semelhança entre as composições pode ser sutil, possibilitando referência mútua entre ambas, muitas vezes dada apenas pelo leitor ou, ainda, inexistente, porque não percebida. Essa equivalência pode estar limitada apenas a interrelações que evidenciam a afirmação das obras como signos uma da outra, atingindo o sentido amplificado do processo de adaptação, que é entendido como uma procura de equidade 
entre dois sistemas distintos através do uso de seus próprios meios de representação. Por esse motivo, aderimos ao termo "tradução" como o que mais se aproxima do trabalho apresentado neste artigo, pois, como mostraremos ao longo da análise fílmica, muitas vezes as relações entre as obras de Shakespeare e o filme de Roland Emmerich são expostas de maneira sutil.

O conceito de adaptação popularmente difundido refere-se principalmente ao caso dos filmes cujas histórias teriam sido primeiramente narradas por obras literárias; no entanto, a compreensão geral acerca desse termo hoje é capaz de abranger diálogos que vão além daquele entre literatura e cinema, abrangendo um sem-número de suportes, como, o balé, a ópera, as webséries, os videogames, os parques temáticos, entre outros. Obras fílmicas cujo enredo advém ou remete a obras literárias, contudo, são muito frequentes e podem ser analisadas sob a perspectiva da hipertextualidade ${ }^{1}$ e, assim, pensadas a partir de conceitos como, por exemplo, de paródia ou sátira, ou da intertextualidade, quando fazem referências a outros textos sem colocar a mesma trama em ação. As concepções de intertextualidade e hipertextualidade (GENETTE, 2010) são amplamente difundidas nos estudos de literatura comparada e, quando reconhecidas pelos espectadores, a essência dos dois conceitos se aproxima, uma vez que a intertextualidade, assim como a hipertextualidade, também se refere à presença de um texto dentro de outro, porém seu caráter contempla relações mais explícitas.

Ao descrever as diferentes espécies de relações entre os textos, Gérard Genette, na obra Palimpsestos: a literatura de segunda mão (2010, p. 12), aponta cinco tipos de interações: intertextualidade, paratextualidade, metatextualidade, hipertextualidade e arquitextualidade. Essas relações transtextuais são numeradas em ordem crescente de abstração, implicação e globalidade. O primeiro conceito delineado pelo teórico, e já explorado anteriormente por Julia Kristeva (1969), é o de intertextualidade, definida por ele como uma relação de co-

\footnotetext{
${ }^{1}$ Genette (2010) expõe como hipertextualidade a relação que une um texto B (hipertexto) a um texto A (hipotexto), do qual ele surge a partir de uma forma que não a de comentário.
} 
presença entre dois ou vários textos, uma presença efetiva de um texto em outro.

A intertextualidade pode se manifestar de diversas formas, sendo a citação direta a mais explícita e literal. Ao falarmos de Shakespeare e do diálogo estabelecido entre a linguagem do teatro e do cinema por meio da adaptação transcultural, podemos citar um exemplo encontrado no filme Ten Things I Hate About You [Dez coisas que eu odeio em você] (1999), de Gil Junger, que, além de manter uma estreita relação com o enredo da peça $A$ megera domada, solidifica a ligação entre os dois textos a partir do momento em que, em uma das cenas, o Soneto 141 de Shakespeare é citado em sala de aula pelo professor de literatura inglesa. Na cena, o professor Morgan transforma o poema em um rap, ou seja, adapta-o para que sua presença se torne condizente com o meio no qual ele circula, mas, ainda assim, a autoria dos versos é atribuída ao dramaturgo, construindo um intertexto que não pode ser negado pelo espectador.

A intertextualidade também pode ser encontrada por meio de vestígios não explícitos. Ao explorar essa prática, Genette aponta para duas direções: o plágio - um empréstimo velado, porém literal, de algum texto -, e a alusão uma presença menos explícita, cuja compreensão plena supõe a percepção de uma interrelação entre textos. Este estado implícito do intertexto é definido por Michael Riffaterre, citado por Genette (2010, p. 15), como “a percepção pelo leitor de relações entre uma obra e outras, que a precederam ou a sucederam". Ainda segundo Rifaterre, “a intertextualidade é [...] o mecanismo próprio da leitura literária. De fato, ela produz a significância por si mesma, enquanto que a leitura linear, comum aos textos literários e não-literários, só produz o sentido" (apud GENETTE, 2010, p. 15). Portanto, a concretização da leitura intertextual depende essencialmente do leitor, pois ele pode considerar a relação hipertexto vs hipotexto ínfima o bastante para não levá-la em conta, ou pode deter-se à presença de um hipotexto e, assim ressignificar a sua leitura.

Ao abordar o conceito de hipertextualidade, Genette (2010, p. 18) define sua ocorrência como toda relação que une um texto B (hipertexto) a um texto A (hipotexto), a partir do qual ele se (re)cria. Essa referência não ocorre na forma 
de comentário - caso da metatextualidade, quando uma obra se refere a outra para comentá-la criticamente -, mas se manifesta como uma presença ativa, capaz de alterar os sentidos a partir de uma leitura que reconhece esse outro.

[...] O hipertexto é mais frequentemente considerado como uma obra "propriamente literária" do que o metatexto - pelo simples fato, entre outros, de que, geralmente derivada de uma obra de ficção (narrativa ou dramática), ele permanece obra de ficção, e, como tal, aos olhos do público entra por assim dizer automaticamente no campo da literatura; mas essa determinação não lhe é essencial, e encontraremos certamente algumas exceções. (GENETTE, 2010, p. 18)

O recurso a alguns conceitos mencionados por Genette torna-se imprescindível quando voltamos nossa atenção a adaptações cinematográficas como a obra Anônimo (2011), que resgata tanto a produção quanto a imagem de um dos dramaturgos mais imitados e copiados. Além da definição do teórico francês acerca do que seria a intertextualidade e a hipertextualidade, também se configura de suma importância apontarmos uma diretriz essencial para a análise apresentada neste trabalho: a construção de sentido a partir da intermidialidade. A partir dos estudos de intermidialidade podemos não apenas pensar as ideias de Genette, trabalhadas aqui a partir do conceito de transmidiação, como também analisar as referências que o filme faz a outra mídia, o teatro, nas formas do texto dramático e do texto cênico.

Em termos gerais, a intermidialidade pode ser definida tanto como a relação entre as mídias e as interações e interferências de cunho midiático, quanto o próprio estudo que analisa essas relações. Segundo Werner Wolf (1999, p. 40-41), um dos pesquisadores da área, “intermidialidade é, em primeiro lugar, um termo flexível e genérico, capaz de designar qualquer fenômeno envolvendo mais de uma mídia". Podemos compreendê-la como um "cruzamento de fronteiras" (CLÜVER, 2007) a partir do momento em que a propriedade de uma mídia passa a habitar outra, por meio da midiação, transferindo suas principais características. 
A palavra "mídia", nesse contexto, pode ser entendida como uma ferramenta da comunicação em suas diferentes perspectivas: as artes (o teatro, o cinema, a literatura etc); os gêneros e subgêneros, dependendo de suas características (a tragédia, o cinema 3D, o romance); os suportes (o palco, a tela, o livro); os materiais e tecnologias (o corpo, o projetor, a linguagem verbal escrita etc). O termo "midiar" refere-se, assim, "ao processo através do qual um meio técnico torna percebível algum tipo de conteúdo de mídia" (ELLESTRÖM, 2017, p. 182), ou seja, as interfaces que permitem que um conteúdo seja enviado e recebido. Ao ler as palavras "por crer, não te amo com meus olhos", o leitor dos Sonetos de Shakespeare tem a mensagem de um poema midiada pela linguagem verbal escrita em um livro. Já ao assistir e ouvir o professor Morgan, de Ten Things I Hate About You (1999), recriar o mesmo soneto, o espectador se depara com uma transmidiação do mesmo texto, o Soneto 141. A transmidiação ocorreu porque o poema, que antes era midiado pela página do livro, foi midiado novamente agora por uma tela e, além disso, ao texto transmidiado foram adicionados outros elementos que correspondem à linguagem própria da nova mídia, como o tom de voz, as características e a expressão do professor, o ambiente em que ocorre, a iluminação e o enquadramento.

O exemplo de transmidiação mais conhecido na esfera artística é o da adaptação cinematográfica, que consiste, geralmente, em um filme transmidiando um romance ou, no caso das adaptações de Shakespeare, peças teatrais. A transmidiação sempre envolve algum tipo de transformação, mesmo aquela que se aproxima a uma simples remidiação de um conteúdo de uma mídia para outra, por exemplo, a passagem de um romance em livro para um ebook, em que a transformação do conteúdo é apenas aquela que se adapta à materialidade da mídia, por exemplo, a digitalização de um texto impresso. Mesmo que a intenção não seja a transformação desse conteúdo, a simples travessia de uma mídia a outra vai exigir algum tipo de adaptação. Assim, ao ler o soneto de Shakespeare em voz alta, já estamos realizando um processo de transmidiação. A adaptação, nesse sentido, é o nome que se costuma dar a um dos tipos de transmidiação, geralmente aquela que envolve mais transformações e que, 
por isso, costuma resultar em um objeto de mídia novo, por exemplo, um musical adaptado de um romance.

Segundo Lars Elleström, em Midialidade: ensaios sobre comunicação, semiótica e intermidialidade (2017), a relação estabelecida entre a intermidialidade e a adaptação é uma relação de subordinação da segunda para a primeira. A adaptação, quando entendida como um fenômeno de mídia, é considerada um tipo de transformação midiática, além de ser, também, um tipo específico de transformação de mídia. Essas transformações se distinguem entre transmidiação, "a representação repetida (embora certamente não idêntica) de características de mídias por um outro tipo de mídia", e representação de mídias, "a representação de um outro tipo de mídia" (ELLESTRÖM, 2017, p. 203). Enquanto a transmidiação consiste em escolher elementos específicos de uma mídia e utilizá-los de outra maneira em outro tipo de mídia, a representação trata de "apontar" para uma mídia a partir do ponto de vista de outro tipo de mídia (ELLESTRÖM, 2017). Em nosso trabalho, vamos mostrar ambas ocorrências em Anônimo.

Ao trazer para as telas a dinâmica dos palcos do Globe, a obra de Roland Emmerich acaba por representar algumas características que pertencem à primeira mídia - o teatro -; no entanto, essas características são percebidas por meio do uso da linguagem da nova mídia que a transmite - o cinema -, fazendo com que o espectador perceba a transposição de uma para outra - ou uma dentro da outra.

\section{Anônimo: a invenção do gênio}

Conhecido por uma filmografia que contempla as catástrofes e os mitos que envolvem o fim do mundo, Roland Emerich utiliza sua experiência em desconstruir símbolos cristalizados da nossa cultura e imaginário para desestabilizar nosso entendimento acerca de quem seria William Shakespeare. É a partir de um roteiro criado em 1998, ironicamente, ou não, o ano em que o filme Shakespereare apaixonado (1998) conquistava o público nos cinemas, que o cineasta decide dar vazão a um debate antigo: seria Shakespeare um gênio ou uma far- 
sa? Nessa tragicomédia cinematográfica, o verdadeiro nome do autor das peças aclamadas pelo público é desconhecido, e Shakespeare, longe de ser um dramaturgo renomado, figura apenas como um ator bêbado e iletrado da companhia Lord Chamberlain's Men.

Ao trazer à tona uma das teorias na qual a autoria das peças de Shakespeare é posta em dúvida, Anônimo (2011) atribui a criação dos textos dramáticos ao Conde Edward de Vere, 17º Conde de Oxford - um patrono das artes, poeta e dramaturgo admirado por seus contemporâneos. $\mathrm{O}$ jogo ficcional de Emerich ganha força ao resgatar, além da polêmica a respeito da invenção de um gênio, o caráter popular destinado às peças teatrais na época, responsável por designá-las como uma arte barata e nada ortodoxa.

Além do enredo audacioso, a narrativa de Anônimo (2011) se configura como um convite à apreciação das técnicas e escolhas utilizadas para contar essa história. Logo na primeira cena, em uma tomada única que exibe um fluxo intenso de carros, a ambientação contemporânea nos situa em uma agitada metrópole, e a câmera, responsável por acompanhar a figura de um homem que salta apressado de um dos inúmeros taxis à vista, logo revela o contexto da cena ao filmar um letreiro de um teatro no qual a peça Anônimo será exibida.

Figura 1: Cena em que o ator se direciona à entrada do teatro

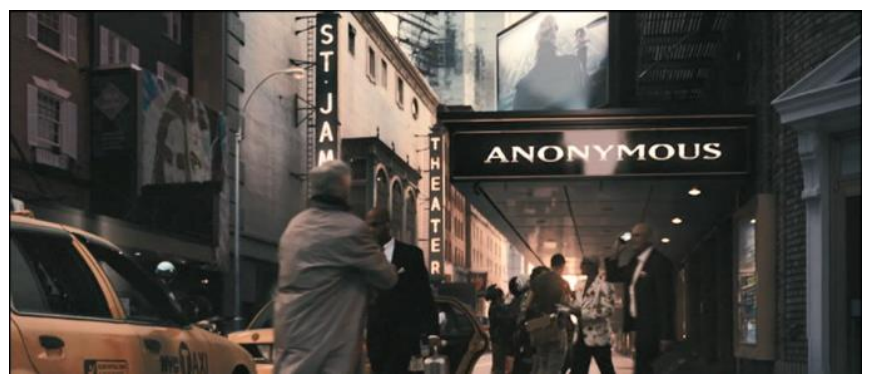

Fonte: Columbia Pictures, 2011

O fato de a peça levar o mesmo nome do filme e de a câmera acompanhar a figura que entra pela porta dos fundos do teatro, exibindo detalhes da 
coxia e da produção da peça, direciona o nosso olhar à exposição da técnica de narração. Aqui, teatro e cinema são duas linguagens complementares, pois uma permite que o espectador tenha acesso à outra. Neste caso, o cinema está representando a mídia teatro, e ainda não temos nenhuma referência à poética shakespeariana.

Figura 2: Cena dos bastidores da peça

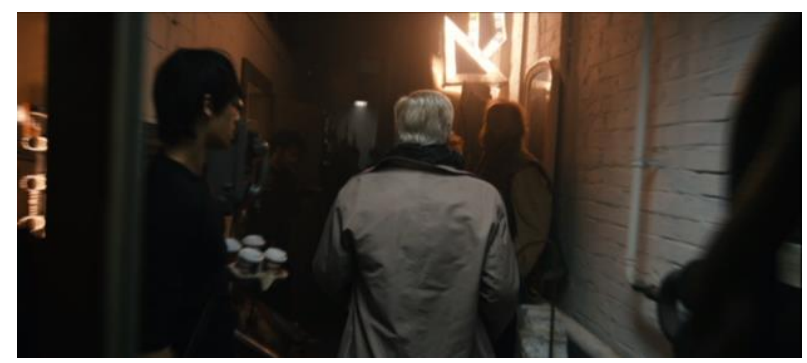

Figura 3: Momentos antes de iniciar a peça

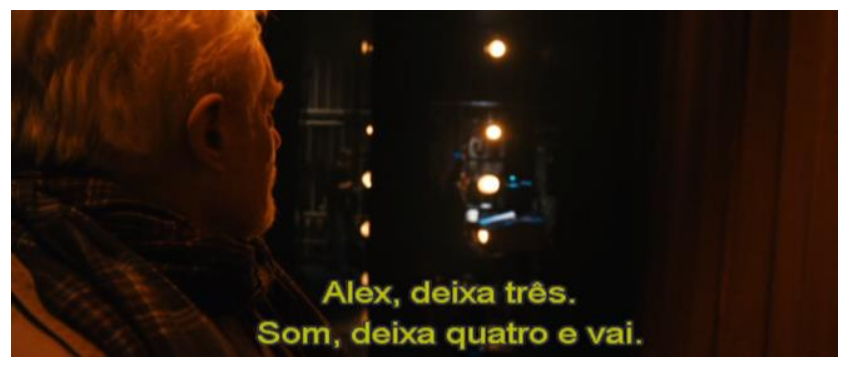

Fonte: Columbia Pictures, 2011

O trajeto que a câmera percorre bem como a seleção de ângulos e acontecimentos ao longo das cenas revelam um novo território ao espectador. Ao assistir a uma peça de teatro, não temos acesso a seus bastidores, nossa visão dá conta apenas do que é mostrado no palco. Neste caso, o espectador enxerga a moldura do teatro, ou seja, ele é dado como uma mídia - o teatro -, não como um objeto de mídia - uma determinada peça. Aqui, a referência ao teatro realiza a tarefa de representar a arte de Shakespeare, criando uma sensação de que 
a história a ser mostrada na tela é aquela que vai ser encenada no palco - o objeto de mídia "Anônimo", imitando um processo de transmidiação, como se a peça fosse filmada para os espectadores do cinema. Ao ver a coxia, o nervosismo dos atores e os ajustes finais da sonoplastia, o espectador tem consciência de que se trata de um filme que representa um instante do teatro. Essa noção, dada pela moldura da mídia teatro, intensifica-se no momento em que o espectador enxerga a cena a partir do palco, não da plateia, intensificando o jogo da representação. Em seguida, a moldura se dilui e o que vemos é a transformação da peça em filme - a peça Anônimo, que antes fazia parte do filme, representando o teatro, transforma-se no filme Anônimo.

Figura 4: Início do prólogo

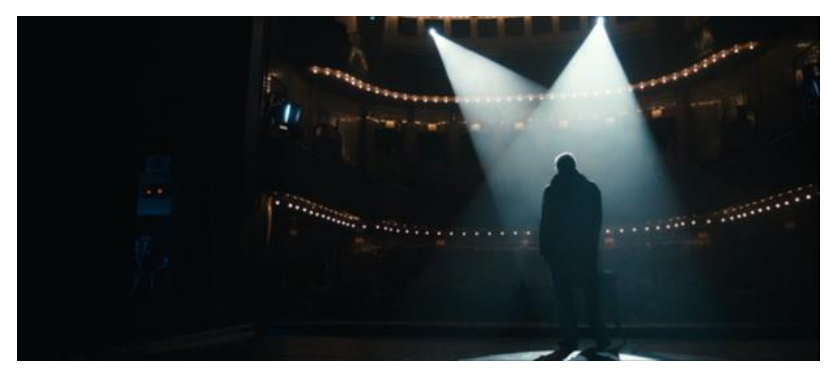

Figura 5: Ator do filme prestes a entrar em palco

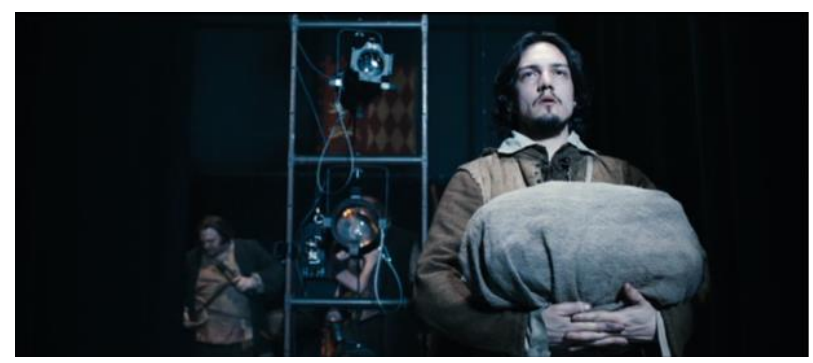

Fonte: Columbia Pictures, 2011 
Nas figuras acima, a exposição dos bastidores e a perspectiva da câmera tornam evidente essa estratégia de representação. No início do prólogo, além de termos uma visão que só nos é permitida a partir do uso da câmera, é possível notar, no decorrer da cena, que no canto esquerdo da cena, há um interruptor e uma placa onde se lê exit - que indica a saída do palco, em uma alegoria muito interessante do que virá a seguir - a saída do palco para a entrada do cinema. Já a figura 5 mostra um dos protagonistas do filme aguardando o momento de adentrar o palco, ou, nessa mesma alegoria, o cinema.

A intenção de trazer à tona o questionamento acerca da autoria das peças de Shakespeare, embasado pela falta de registros que comprovem sua escolaridade ou até mesmo pela inexistência de manuscritos de suas peças, é explicitada desde o prólogo apresentado. O responsável por incitar a dúvida naqueles que assistem ao filme - pois ele fala para a câmera - é o ator Derek Jacobi, celebrado por seus papeis shakespearianos no teatro e no cinema e um defensor da teoria oxfordiana, já aqui explicitada.

Figura 6: Prólogo que inicia o filme

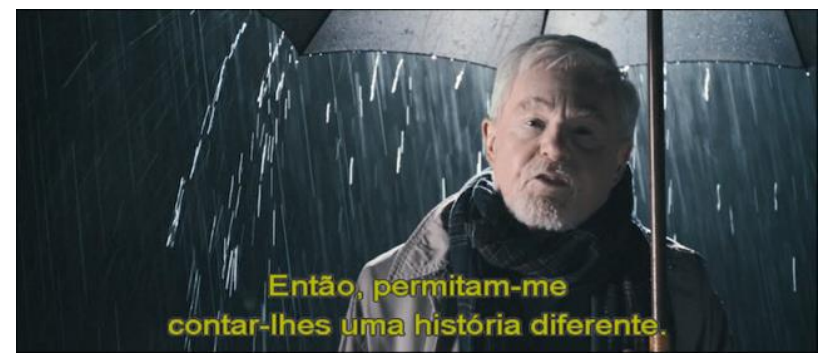

Figura 7: Encerramento do filme

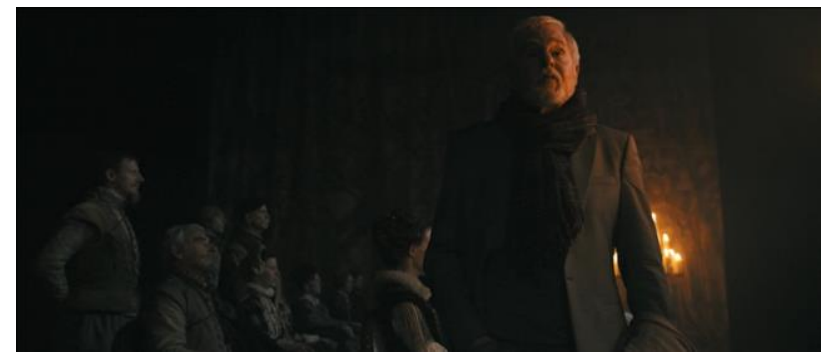


Assim, o diálogo intermidiático presente em Anônimo (2011) é tecido em dois pontos estratégicos do filme: no início, a partir do prólogo que situa o espectador a respeito do tema da narrativa (figura 6); e ao final, como uma espécie de posfácio, no qual o ator Derek Jacobi, cujo personagem não tem nome, encerra a narrativa com alguns fatos que corroboram a teoria recém “encenada" pelos atores do filme/peça (figura 7).

Em um filme que explora a questão da autoria como mote para seu enredo e que apresenta cuidadosamente o nome de seus personagens a fim de fazer referência à biografia e ao contexto real de Shakespeare, transformando o verossímil em "verídico", causa estranheza a falta do nome dessa personagem responsável por iniciar e encerrar a narração, que usa vestes comuns e não o figurino da peça. Mas é uma estratégia que, deixando o ator teatral de fora da "peça" em si, possibilita que aquele que assiste ao filme associe a figura do comentarista à do ator Derek Jacobi, e toda a carga simbólica que sua presença conota no que diz respeito ao mundo do teatro torna-se um reforço ao argumento apresentado pelo filme. Assim como ocorre com os vários vestígios intertextuais que permeiam a obra, apresentar a figura de Jacobi significa endossar a teoria de que Shakespeare não passa de uma invenção. Nesse sentido, o ator é uma representação do mundo real, que ocupa um espaço no filme, relativizando a própria moldura da mídia cinema, sobretudo quando derruba a quarta parede e se dirige ao espectador.

A força com que a narração manifesta sua premissa está presente nas estratégias que o filme utiliza para indagar a autoria das peças apresentadas. Salvo o início do filme, no qual a dúvida é claramente apresentada no prólogo, a ligação entre a invenção do gênio e a identidade do verdadeiro autor dos dramas é evidenciada por meio do caráter e das ações dos personagens e não de afirmações verbais. É interessante observar que Shakespeare sequer é o protagonista do filme, mas, sim, o próprio Conde de Oxford, o verdadeiro gênio que precisa esconder-se da criação por ser um amante anônimo da Rainha Eli- 
zabeth I. Citamos dois momentos em que a invenção deste Shakespeare dramaturgo é manifestada:

Figura 8: Shakespeare molha o dedo no tinteiro

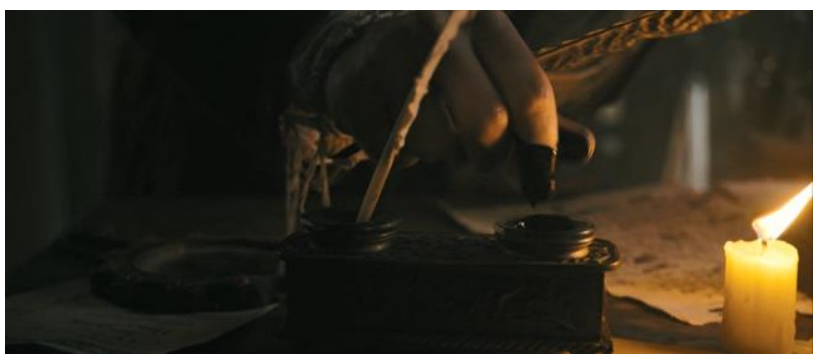

Figura 9: Shakespeare assume a autoria da peça

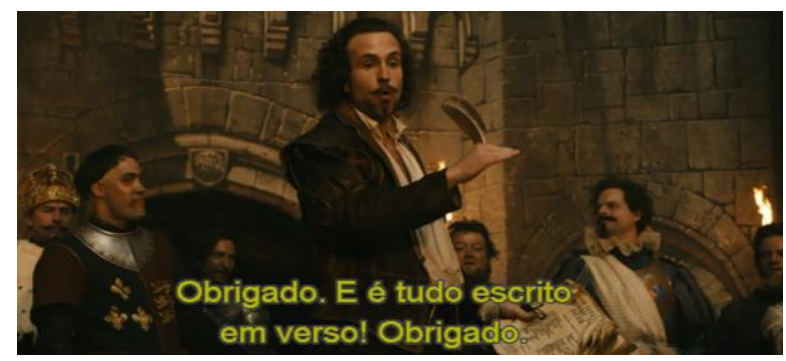

onte: Columbia Pictures, 2011

As imagens acima ilustram uma sequência de cenas na qual Shakespeare, ainda na condição de ator da companhia, decide reivindicar a autoria da peça Henrique $V$ ao testemunhar a euforia e o envolvimento de uma plateia que clama pelo autor do drama encenado no palco e que, para esse público, era desconhecido. Para a companhia, a autoria era anônima, a não ser para Ben Jonson, que é justamente quem faz o acordo com o Conde De Vere para que suas peças sejam encenadas sem que ele apareça como autor. Ou seja, os espectadores do filme sabem da invenção, mas os espectadores do teatro, os verdadeiros receptores de Shakespeare, são enganados. Estimulado por um coro que clamava "dramaturgo! dramaturgo!", o ator William Shakespeare decide pegar o manuscrito que se encontra em uma mesa, nos bastidores, e se apresentar à 
plateia. Para dar mais veracidade à sua atitude, tendo em vista que o seu faltoso histórico escolar e sua duvidosa capacidade de criação são conhecidos pelos integrantes da companhia, ele decide mergulhar os dedos no tinteiro (figura 8) em alusão a um dos símbolos dos escritores da época - os dedos manchados de tinta. Essa cena interessa pela referência intermidiática ao texto dramático, e não à encenação, mostrando pena, tinta e papel, bem como a caligrafia da época, novamente trabalhando com a representação da mídia teatro, neste caso, o texto dramático.

Outra ocasião que expõe o processo de criação da figura de Shakespeare como um dramaturgo é o momento em que o Conde Edward de Vere, após ter entregado sua peça Henrique $V$ a Ben Jonson, e sua autoria ter sido vinculada a Shakespeare, forja uma assinatura para o ator.

Figura 10: Conde Edward de Vere forja uma assinatura para William Shakespeare

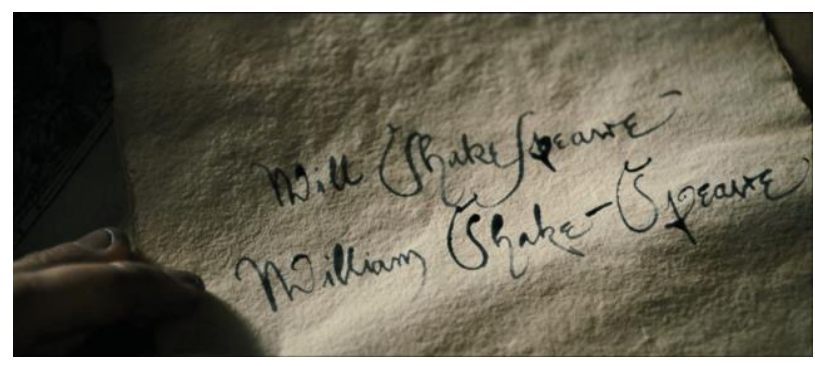

Fonte: Columbia Pictures, 2011

Na figura acima, podemos ver o momento em que o Conde treina diferentes opções de assinatura até chegar ao que hoje conhecemos como a assinatura de Shakespeare. A necessidade de a assinatura ser forjada pelo Conde tem relação com o fato de o bardo, no filme, ser incapaz de escrever. Sua inabilidade com as letras, junto com seu famoso envolvimento com a bebida, é tema das conversas dos personagens que o conhecem e que dividem os palcos com ele, mostrando a dúvida, que é apenas deles, a respeito da veracidade da autoria 
das peças, visto que apenas o espectador teve acesso à armação. Em Anônimo (2011), Shakespeare é frequentemente retratado como um ator bonachão que estima mais o tempo que passa na taberna com outros bêbados do que os momentos em que supostamente criaria seus famosos versos.

\section{Figura 11: Shakespeare após uma apresentação}

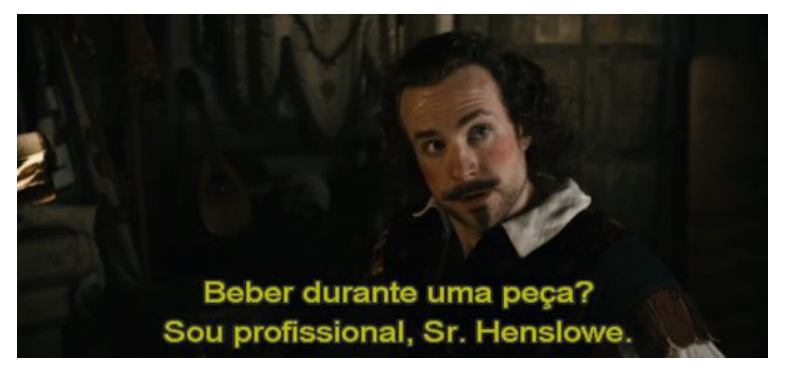

Figura 12: Shakespeare e Ben Jonson

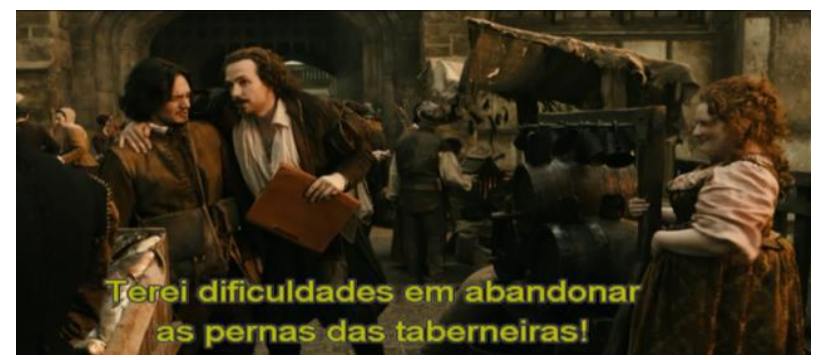

Fonte: Columbia Pictures, 2011

Apesar da existência de documentos que permitiram que fossem delineadas biografias de Shakespeare, por exemplo, as de Park Honan (Shakespeare, a Life,1999) e de Stephen Greenblatt (Como Shakespeare se tornou Shakespeare, 2007), bem como estudos sobre a autoria das obras, como o de James Shapiro (Quem escreveu Shakespeare?, 2010), ainda existem muitas controvérsias sobre a vida do bardo. Além disso, embora seu nome seja talvez um dos mais conhecidos e citados, segmentos de sua trajetória pessoal ainda são desconhecidos, como os anos que antecedem sua chegada a Londres. Essas lacunas acabam 
por permitir que o filme explore esse lado obscuro e fértil, resgatando e inventando uma imagem do bardo que, embora bastante fabulística e contestável, torna-se, como ficção, plausível, pela referência a personagens e ao contexto da época, bem como às próprias obras. Nesse sentido, podemos entender que essa invenção pode ser compreendida como uma alegoria, ao trabalhar com essa colagem de representações, que unem um ator que conhece os palcos e a vida mundana a um poeta erudito que compreende as relações humanas e dispõe de tempo para elaborar e escrever. Ao longo da história das artes, as manifestações alegóricas se efetivaram como uma interlocução entre diferentes tempos - um presente que fala de um passado.

Elemento estrutural próprio da literatura, a alegoria possui um aspecto metatextual que se faz presente sempre que um texto é dublado por outro; ou seja, na estrutura alegórica um texto é lido através de outro, independentemente do quão fragmentada ou caótica essa ligação possa ser (OWENS, 2004). De acordo com Craig Owens (2004, p. 114):

\footnotetext{
o imaginário alegórico é um imaginário apropriado; o alegorista não inventa imagens, mas as confisca. Ele reivindica o significado culturalmente, coloca-a como sua intérprete. E em suas mãos a imagem torna-se uma outra coisa. Ela não restaura um significado original que possa ter sido perdido ou obscurecido; a alegoria não é hermenêutica. Mais do que isso, ela anexa outro significado à imagem. Ao anexar, no entanto, faz somente uma recolocação: o significado alegórico suplanta seu antecedente; ele é um suplemento.
}

Em Anônimo (2011), dentre tantas motivações, são justamente as lacunas na história e a dificuldade, talvez preconceituosa, de enxergar a genialidade em um homem comum, que permitem que nos apropriemos da imagem de Shakespeare para reinventá-la em um presente. A partir do impulso alegórico podemos ressignificar aquela idealização sobre quem teria sido o dramaturgo de Stratford-Upon-Avon, como um um homem erudito e nobre, mais próximo do personagem de Conde De Vere. 
A ressignificação da imagem de Shakespeare dada pelo filme mostra-o como um ator insensível ao poder da poesia. Descrente da influência que os versos das peças que levavam seu nome poderiam exercer em seu público única instância a valorizá-lo -, o pseudo-dramaturgo não esconde que sua verdadeira pretensão é atingir um status de respeito diante dos olhos de seus colegas. Para isso, Shakespeare aceita prontamente a proposta de Edward de tomar para si a autoria das peças encenadas. Ao contrário do ator, o Conde, por acreditar que suas palavras exprimam poder, deseja que suas peças sejam encenadas em teatros públicos, mesmo que para isso ele tenha de abrir mão da autoria de seus escritos. Sentado em seu camarote, assistindo aos espetáculos, ele tem consciência do poder de suas palavras.

Figura 13: O Conde fala sobre o poder do Teatro

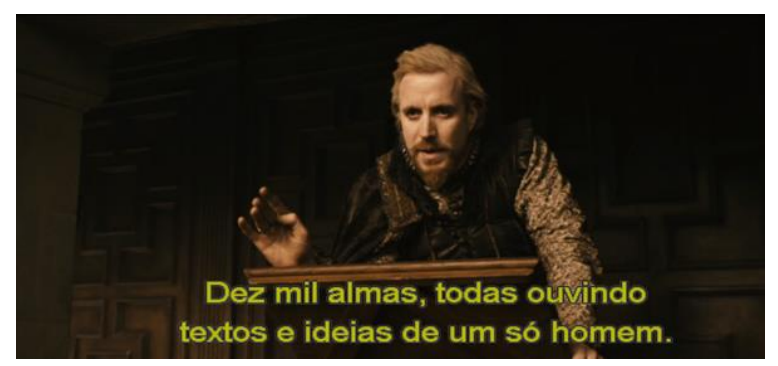

Figura 14: $\mathrm{O}$ poder das palavras

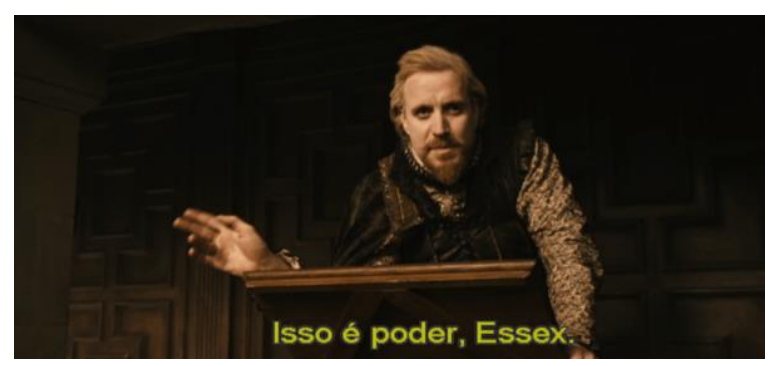

Fonte: Columbia Pictures, 2011 
É importante ressaltarmos que o enredo do filme divide seu interesse entre a alegoria sobre Shakespeare e a relação do Conde Edward com a rainha Elizabeth I, e que essa relação entre o verdadeiro protagonista do filme e a soberana é essencial para a verossimilhança da trama. Edward de Vere precisa esconder sua autoria porque o amor que ele nutre pela rainha é desaprovado, e assim ele tem de se declarar a ela através de seus versos, pois, assim como ele, ela possui uma admiração pelo teatro, que é o elo entre eles e que os fez apaixonarem-se um pelo outro quando ele era apenas um jovenzinho entusiasmado pela arte cênica.

Figura 15: Momento em que a rainha e Edward conversam após a apresentação de uma peça

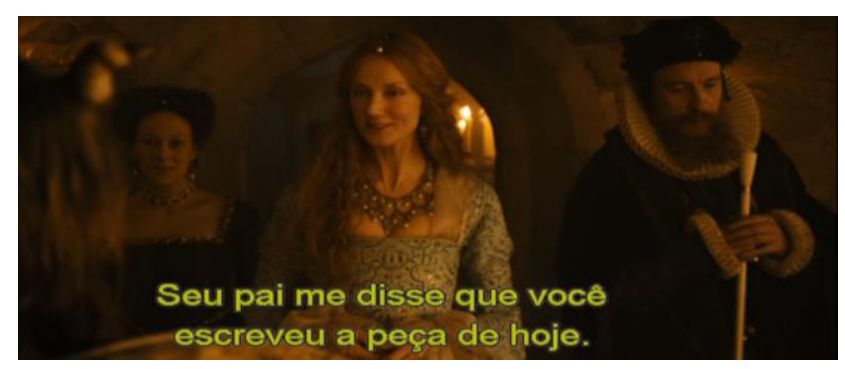

Fonte: Columbia Pictures, 2011

A imagem acima ilustra o momento em que a rainha, após assistir a uma peça escrita pelo jovem Edward, pergunta a respeito da autoria da composição. Como resposta, Edward diz que "for truth is truth though never so old, and time cannot make that false which was once true" ${ }^{2}$, assumindo a posição de autor da peça. A citação é um excerto da carta de Edward de Vere a seu cunhado (ANDERSON, 2005), Robert Cecile, também personagem no filme, e exerce a função de corroborar a verdade factual, trazendo biografemas do verdadeiro Conde De Vere. Aqui, temos a transmidiação de um trecho da

2 “porque a verdade é a verdade, embora nunca tão antiga, e o tempo não pode fazer com que seja falso o que uma vez foi verdade" (tradução nossa). 
carta, do papel, para a voz do Conde, transformada pelo contexto, bastante oportuno para seu sentido.

A todo momento, as composições que hoje atribuímos a Shakespeare são, de alguma maneira, relacionadas a Edward de Vere, já que uma de suas aspirações era presentear a rainha com suas criações.

Figura 16: A rainha Elizabeth I e Edward durante um baile da corte
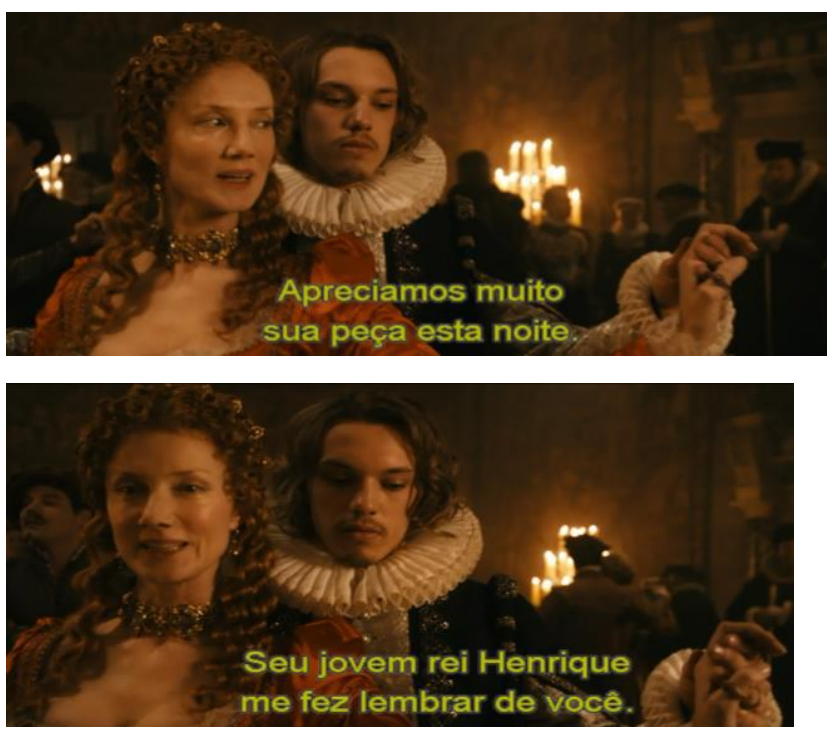

Fonte: Columbia Pictures, 2011

Esses intertextos de Shakespeare - referências a suas obras - então relacionados a De Vere são intermidiados sobretudo de duas maneiras. Em diversos momentos da narração, as peças de Shakespeare aparecem por meio de referências diretas aos seus títulos, às personagens ou a alguma particularidade do enredo que é conhecida pelo grande público, mostrando-se como representações de objetos de mídia - as peças especificamente. Porém, há situações em que as referências feitas às composições do bardo se mantêm veladas por trás de diálogos que mascaram as citações, tornando-as mais tênues à medida que são incorporadas a outras falas. Por se imiscuírem no enredo do filme a partir de seus sentidos complexos, podemos entendê-las como a transmidiação 
de elementos das peças. Neste caso, não enxergamos a mídia teatro, mas seus sentidos são transportados ao filme, um processo de transmidiação que adapta os elementos dos textos dramáticos ao enredo do filme.

Figura 17: Em um diálogo, a rainha Elizabeth I cita a canção de Noite de Reis
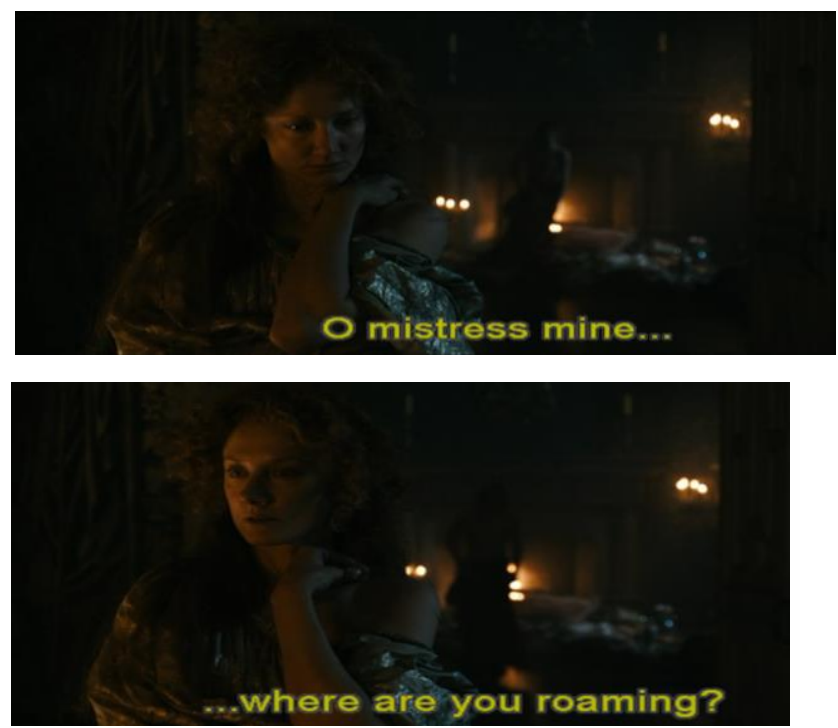

Fonte: Columbia Pictures, 2011

Já aquelas referências que se mostram como tais, a partir de suas molduras visíveis - são peças de teatro - têm a intenção de representar a produção do bardo, fazendo referência tanto aos objetos de mídia quanto ao próprio dramaturgo ou à sua arte, o texto dramático.

Figura 18: Manuscrito de A tragédia de Júlio César

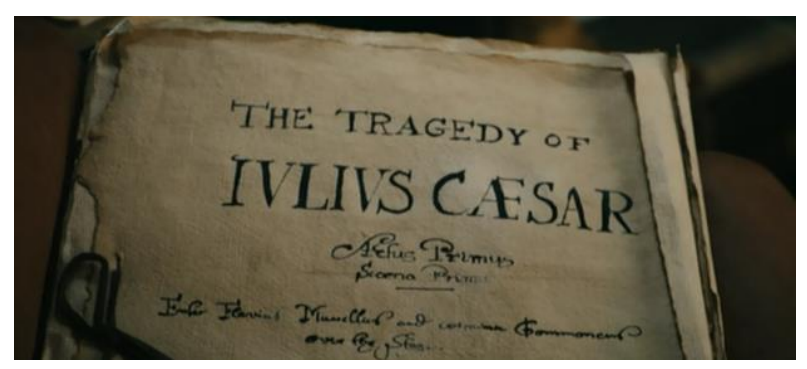


Figura 19: Manuscrito de Macbeth

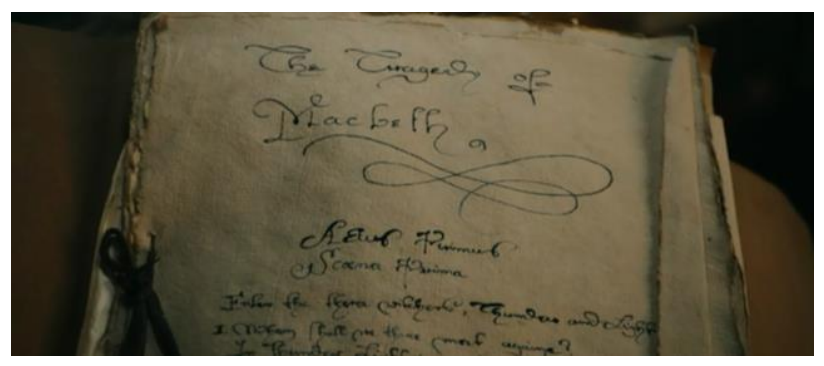

Fonte: Columbia Pictures, 2011

As imagens acima representam o momento em que o Conde Edward de Vere procura entre alguns manuscritos a peça que entregará a Ben Jonson. Entre tantas peças já escritas, como A tragédia de Júlio César e Macbeth (Figuras 20 e 21), o autor se depara com Romeu e Julieta e decide que essa será a nova peça encenada, deixando transparecer seu favoritismo pela história dos dois jovens que, mesmo apaixonados, são impossibilitados de ficarem juntos, tal como ele e a Rainha.

Figura 20: Edward pega em mãos o manuscrito de Romeo e Julieta

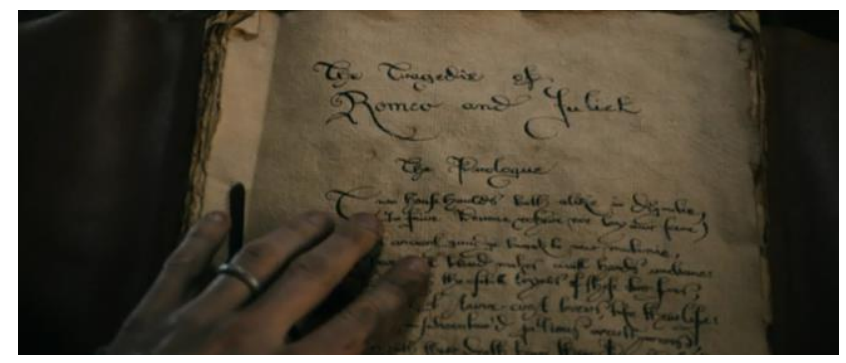

Fonte: Columbia Pictures, 2011

Na imagem acima, podemos ver o contraste entre a paixão que Edward devota à rainha (expressa pelos versos de Romeu e Julieta) e a impossibilidade desse amor se realizar (por meio da presença da aliança em sua mão). 
Outras referências às peças que podem ser entendidas como representações de objetos de mídia são os cartazes que anunciam os espetáculos, claramente mostrando-se como tal.

Figura 21: Cartaz da tragédia Macbeth

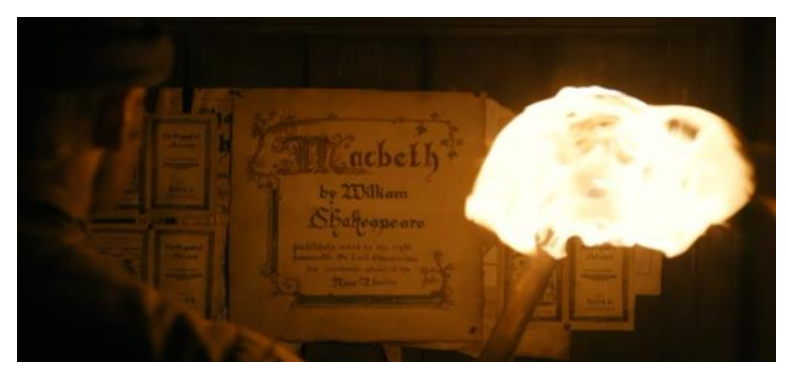

Figura 22: Cartaz da tragédia Macbeth

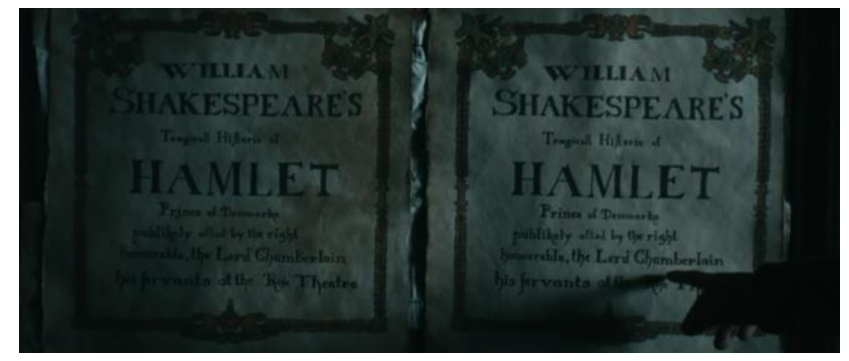

Fonte: Columbia Pictures, 2011

Ao longo da narrativa, a presença desses cartazes é o anúncio de que o mito se cristaliza, pois os manuscritos que são entregues a Ben Jonson passam a ser apresentados nos palcos e se tornam um sucesso de público e crítica. Tanto as tragédias quanto as comédias passam a ser encenadas também dentro da corte, elevando o nome de Shakespeare ao status de maior dramaturgo da época, aquele que hoje conhecemos como um gênio.

\section{Considerações finais}

O filme, como alegoria da invenção do bardo, constrói-se através das várias representações: da mídia teatro - a partir do palco, das coxias, do preparo dos 
atores, da visão da plateia; pela referência ao texto dramático, a partir das imagens dos próprios textos em papel, e pela citação direta aos objetos de mídia, pelos títulos e personagens. Também se constrói pela transmidiação de trechos dos textos cênicos, quando as peças são encenadas no palco, e pela transformação de trechos das peças em cenas do filme, transmidiando o texto dramático em enredo do texto cinematográfico. São vários processos transmidiáticos que criam essa relação entre o teatro e o cinema, fazendo também com que o espectador dos palcos, admirador ou não de Shakespeare, mescle-se ao espectador do filme. Nessa posição, cabe a ele decidir-se sobre esse "ser ou não ser", entre a alegoria, a invenção, o drama, ou uma possibilidade de que a arte também constrói seus mitos, pela ficção, fora dos palcos e das telas.

\section{Referências}

ANDERSON. Mark. Shakespeare by another name: The Life of Edward de Vere, Earl of Oxford, the Man Who Was Shakespeare. California: Untreed Reads, 2005.

CLÜVER, Claus. Intermidialidade. Pós, Belo Horizonte, v. 1, n.2, 8-23, nov. 2007.

DINIZ, Thaïs Flores Nogueira. Literatura e cinema: da semiótica à tradução. Ouro Preto: UFOP, 1999.

ELLESTRÖM. Lars. Midialidade: ensaios sobre comunicação, semiótica e intermidialidade. In: DOMINGOS, Ana Cláudia Munari; KLAUCK, Ana Paula; MELO, Glória Maria Guiné de (Orgs.) Porto Alegre: EDIPUCRS, 2017.

EMMERICH. Roland; ORLOFF, John. Anônimo [Filme-vídeo]. Direção e produção de Roland Emmerich, roteiro de John Orloff. Columbia Pictures, 2011, 130 minutos, son., color.

GENETTE. Gérard. Palimpsestos: a literatura de segunda mão. Trad. Cibele Braga; Erika Viviane Costa Vieira; Luciene Guimarães; Maria Antônia Ramos Coutinho; Mariana Mendes Arruda; Miriam Vieira. Belo Horizonte: Viva Voz, 2010. 
HELIODORA, Barbara. Os teatros no tempo de Shakespeare. In: LEÃO, Liana de Camargo; SANTOS, Marlene Soares dos (Orgs.) Shakespeare, sua época e sua obra. Curitiba: Beatrice, 2008. p. 68 -79.

JUNGER, Gil; LUTZ, Karen McCullah; SMITH, Kristen. 10 coisas que odeio em você [Filme-vídeo]. Direção de Gil Junger, roteiro de Karen McCullah Lutz e Kristen Smith. Touchstone Pictures, 1999, 97 minutos, son., color.

KAAYA, B. NELSON, T. B. O [Filme-vídeo]. Produção de Brad Kaaya, direção de Tim Blake Nelson. Imagem Filmes, 2001. DVD, 95 min, son., color.

KRISTEVA, Julia. Introdução à semanálise. São Paulo: Debates, 1969.

MADDEN, John; NORMAN, Marc; STOPPARD, Tom. Shakespeare apaixonado [Filme-vídeo]. Direção de John Madden, roteiro de Marc Norman e Tom Stoppard. Universal Pictures, 1998, 123 minutos, son., color.

OWENS. Craig. O impulso alegórico: sobre uma teoria do pós-modernismo. Arte \& Ensaios, 23, nov 2004. Programa de Pós-Graduação em Artes Visuais/EBA, UFRJ. Disponível em https://www.ppgav.eba.ufrj.br/wpcontent/uploads/2012/01/ae11 craig owens.pdf Acesso em 01 mar 2018.

SHAKESPEARE, William. 50 sonetos. Trad. Ivo Barroso. Rio de Janeiro: Nova Fronteira, 2012.

\section{Resumo}

Neste trabalho analisamos, a partir de processos intermidiais, a figuração de William Shakespeare como alegoria no filme Anônimo (2011), de Roland Emmerich. Consideramos que a construção do dramaturgo como uma personagem que contraria a imagem já cristalizada do bardo erudito se dá a partir de diferentes estratégias intertextuais (GENETTE, 2010) e intermidiais (WOLF, 1999; CLÜVER, 2007; ELLESTRÖM, 2017) que, amparadas pelo "impulso alegórico" (OWENS, 2004), buscam, por meio da linguagem cinematográfica, representar e transmidiar a mídia teatro.

Palavras-chave: William Shakespeare; intertextualidade; intermidialidade. 


\begin{abstract}
In this paper, we analyze, on the basis of intermedial, processes the figuration of William Shakespeare as an allegory in the movie Anonymous (2011), by Roland Emmerich. We consider that the construction of the playwright as a character that contradicts the already crystallized image is based on different intertextual (GENETTE, 2010) and intermedial strategies (WOLF, 1999; CLÜVER, 2007; ELLESTRÖM, 2017) which, supported by "the allegorical impulse" (OWENS, 2004), seek, through cinematographic language, to represent and to transmediate theater as a medium.
\end{abstract}

Keywords: William Shakespeare; intertextuality; intermediality. 